\title{
An analitical extended book review. S. Frunză: Advertising constructs reality (2014)
}

\author{
Ștefan Vlăduțescu ${ }^{1 *}$, Mirela Teodorescu ${ }^{2}$ \\ ${ }^{1}$ University of Craiova, 13 A. I. Cuza Street, 200585, Craiova, Romania \\ 2 Independent Researcher, Craiova, Romania \\ *E-mail address: stefan.vladutescu@yahoo.com
}

\begin{abstract}
As communication axis, communication philosophy interrogates the idea that in postmodern society communication constructs reality. The philosopher is called to achieve a new synthesis, between philosophy and media communication, to assume the condition of man of media communication. Media has a decisive influence in relation to the constitution of reality in post-modern consciousness. Communication is related to relationships, to construct interhuman relationships, changing the attitudes of the other, decisions or behavior of others, the perceptions of reality and action according to the requirements of this perception. Secularization as a positive value of modernity does not eliminate the presence of the sacred in modern political imaginary also from communication. Advertising is by exellence the bearer of a deep dimension of reality construction as art of seduction, persuasion, communication. "Advertising constructs reality", professor Sandu Frunza's book, published in 2014 by Tritonic Publishing, Bucharest, represents a high level analisys and point out the "reality construction" through advertising as a communication mean of regaining authenticity. Storing an imaginary universe, which allows for the sacred to be manifest in the life of postmodern man, advertising supports the human being in its self quest through reaching harmony with the surrounding things, with other people and with the world. Advertising is not a new form of religion, even though several of its aspects could be said to be displaying religious dimensions. "We can, says Sandu Frunza, however, state generically that advertising ultimately lodges posmodern man's religious creativity. In this way, advertising does not propose to challenge or oppose in any fashion the traditional religious patterns of interpreting and living within our world. Instead, it supplies a complementary authenticity, one matching man's status in a communication-based society". Advertising offers an alternative view on the world, man and man's own choice to act coherently upon this view.
\end{abstract}

Keywords: advertising; myth; totem; taboo; fetishism; sacral

\section{INTRODUCTION}

"The discussion about "reality construction" has become, in the meantime, inflated to and not only throughout the entire arts, social and cultural sciences but also in disciplines such as: mathematics, biology, physics or architecture. It appears as if it is a central discovery of postmodern science that more or less 'everything' is constructed - space and time as well as xenophobia; sex and gender as much as the reality of mass media" shows Stefan Weber.

"Reality construction of actors are subject-bound but not subjective in the sense of arbitrary, intentional or relativistic. And that is because in the construction of reality 
individuals [...] are always too late. Everything which becomes conscious first assumes the unattainable neuronal activity of consciousness; everything which is said presumes an already unconsciously acquired mastery of language; how things will be talked about and with what effect. All of this pre-supposes socially regulated and culturally programmed discourses within the social system. In this respect these processes organize the reality construction of themselves and thus create their own ordering of realit(y)ies." (Schmidt 2000).

Professor Sandu Frunza is aware that the mass culture created by media is "that of a reality that contains, as default dimension, the new forms of religiosity whose possibility of emergence is facilitated by a new way of relating to transcendence". In this context, "the mythic structures of the language of advertising, as the new forms of spiritual and cosmic integration in the meaning of human existence, become possible due to the weak transcendence that leaves room for a plurality of options regarding how to appropriate the sacred and the experience of religiosity. They can be found in the plurality of meanings that make the promise of a wide variety of existential encounters with what is meaningful and authentic for each individual". It is emphasized the individual who belongs to the postmodern mass that "allows itself to be seduced by the promise of an encounter that appears to be quite different. This expectation of the encounter with what is different is obviously an expectation of the encounter with the otherness represented by the sacred" (Frunza, 2011a).

Under the pressure of a constant search of authenticity, the man of the consumerist society is placed at the interface between secularization and continous need of the human being of sacred and ritualization, professor Sandu Frunza is concerned of this idea based on the principle of the dialectic of the sacred and the profane, which explains the phenomenon of the crisis of institutionalized religion from the perspective of accepting the image of the weak transcendence as the global background of religiosity.

\section{ADVERTISING CONSRUCTS REALITY}

"Advertising constructs reality" is a book that gathers concepts such as: Seduction and advertising, Fetishism, commodity and advertising, Taboo, interdictions and advertising, Postmodern totem and advertising, Political advertising and the rediscovery of intersubjectivity in the public space, Final thoughts: the return of authenticity. These concepts are deployed, analyzed, interpreted comparing the past with present and the future. Each presented concept represents a chapter of the book emphases the role of advertising as a religion in domain.

\subsection{A symbolic construct of reality under the sign o fragmentary}

In this chapter professor Sandu Frunza shows that advertising is the last refuge of symbolic and ritualistic behaviors, the repository of the sacred par excellence, despite appearing in the form of "imaginative constructions that some find difficult to associate with the sacred or with the religious". Advertising language, expressed in prints, performances and especially in advertising clips, proves to be a kind of concentrated story with the capacity to turn into a significant story. It constructs reality as "a microcosm, in a similar way to that in which grand narratives used to contruct reality as a macrocosm" (p. 7).

Professor Sancu Frunza, evokes M. Paraschivescu's notes regarding M. Eliade's remarks, "literature conjures imaginary worlds with their own laws, and certain qualities of time and space that are not unlike the sacred space and time" (Mihaela Paraschivescu, The 
Critical Reception of Mircea Eliade's Works in the United States of America), because Western human being, shows professor Frunza, no longer has the patience to listen to the story that the world around tells while casting light against the turmoil of life. On rare occasions does "postmodern human being sense that it is actually the story one would like to tell of oneself when, cut off from daily life, regains the strength to find oneself" (p. 9).

Advertising, shows professor Frunza, takes into account a feature of the present humanity: "some refuses totality, the imaginary of totality and the totalizing spirit so as to better perceive the fragmentary, to enjoy pieces of reality marked by specific elements of one's existence, to creatively valorize the possibility to construct one's own world of reality fragments" (p. 11), also it uses something inherent to human soul: the pasion and initiation. Advertising is an effort for direction in culture as any initiation plans to be. It reflects and permanently nourishes the symbolic dimension of consumer culture. In a world in which spiritual values are pushed to a secondary level, this new culture propeses investing this spiritual dimension into our relationship with things. Moreover, "advertising proposes accepting cut-outs in the totality of things following the religious model in which objects of immediate reality become entirely different in their sacralization process while they become hierophanies" (p. 14).

The reality comnstructed by advertising implies a new communication axiology, perennial values are held back due to the secondary part of classical values in contemporary man's life, new value systems of value volatility as a principle are created. Symbolic communication becomes "the field of a social ritualization, of emotion manipulation by use of mythic imaginary, of symbolic integrity by consecration in communication acts" (p. 18). In this context, advertising discourse appears as the harmonious framework of language, thought and action resignification.

\subsection{Seduction and advertising: Awaiting seduction; The world of objects and the seduction of the artificial as ineffable}

The term seduction covers a wide range of feelings, expectations, and modes of being, having and possesing, it involves the integer human being conceived as a corporal and a spiritual being.Seduction analysis process, is made relating to Mark Jeffreis's book The Art of Business Seduction, who remarks items of seduction in communication supposing an emotional registry, a relational one, and an imaginative one correlated to the self-image. Mark Jeffre proposes an I nitiation way that involves communication and seduction techniques summed-up in the phrase L-WAR (Listen, Watch, Anticipate, React) aimed at synthesing a way of business life in which winning one's trust and keeping it plays an important part in the seduction process.

In communication, the seducer and the seduced may permanently valorize each other. This is another reason to contribute to the development of a network structure in which the game of seduction should manifest in forms of daily relations and interpersonal life, in economics, politics, etc. The seducer is permanently for cultivating an ever broader communication domain. In the wolrld of communication, seduction does not pertain to knowledge or possession, it is a practice aimed at the will to situate in a certain existential order and to act according to the logic operating in its open horizon. It helps bring together theory and practice into the act of engaging in the world and transforming the world. 


\subsection{Fetishism, commodity and advertising: A circumspription of the fetish concept}

The author, professor Sandu Frunza, analyses in this chapter, the role of fetish in advertising, it being a complex presence, which intervenes in variuos circumstances and with various functions, in a consumerist cuture, "the advertising itself can be perceived as a fetish" (p. 58).

The fetish brings out the idea of an exagerated desire. The presence of this existential tension overcomes the frame of the simple psychological manifestations, whether they are natural or potentially pathological.

Desire must be philosophically grounded, even if the theories of communication, including those reffering to advertising, are constantly struggling to break from philosophical reflection. It is obvious that such a separation is not welcome. It might condemn advertising to losing an essential reflexive element, specific, intrinsic to the advertising speech - this could contribute to increase the danger of advertising being absorbed by other disciplines and fields of economic communication.

The separation from philosophy can be perceived according to the model that Jurgen Habermas found in Marx, consisting of trying to annul philosophy as a manner to contribute to its preservation. There are deployed three forms of separation from philosophy: therapeutical form, the heroic form and the redeeming "springs of illumination and spiritual awakening" (Habermas, 2000). In a consumer society, "the fetish can function as a tool to understand visual consumtion, which is at the heart of present -day life", is Guy Debord'statement evoked by professor Frunza (p. 75).

\subsection{Taboo, interdictions and advertising: the significance of taboo; taboo and the world of interdictions}

The idea of taboo asserts professor Frunza, has its roots in a "religious ground meaning something which is forbidden, dangerous, inaccesible, impure, or contagious" (p. 91). It is present in all cultures, regarding an interdiction that concerns the sacredness.

Taboo always implies a selection, it is ambivalent, it equally attracts and rejects. Some theoreticians regard the taboo as a mysterious reality, as a feature that has something to hide. To reveal this idea professor Frunza evokes Eliade's asserts that "some things, persons or spaces participate in a totally different ontological system, and as a result, any contact with them produces an ontology breach that can be fatal" (p. 92)

The advertising imaginary must face the controversies and the challenges caused by the presence of taboo in the lives of individuals and of the community. They must know how to handle radical positions and to decrease the major impact of taboos that concern the individual's existence in the world.

Elements that derive from the presence of sacredeness in the life of the postmodern individual can be integrated in the advertising discourse as cultural premises of persuasion. It must be considered the fact that, despite cultural globalization, "we are all tributary to our culture and, as a result, we usually overlook the patterns of behavior which influence the way and the means in which we are being persuaded" as Charles Larson asserts (p. 112).

\subsection{Postmodern totem and advertising: totem and advertising representations}

The totem, is a very present element in the existence of the postmodern individual. Even if its meaning has undergone multiple changes, the totemism can be found in the structure of 
symbolic mechanisms accessed by the contemporary man. "The symbolic way of thinking regarding the totem has the ability to reintegrate the human being in a familiar environment, not understood as a totalized factor, but as a way of emphasizing his fragmentary existence, integrated in a special correlation of interacting elements" (p. 117).

Western advertisment, as other fields (such as communication, ethics, knowledge or economy), is related to the way in which the Western imaginary is structured and to the central role man plays in the hierarchy of the world. In the Western we were accustomed to the image of "the human placed by the deity in the center of Creation and subject to the challenge of coping with a hierarchic and totalized universe in which man serves God, and the created world is destined to serve the human kind" (p. 119). Postmodern toteism rebuilds the "intersubjective connection between man, the world of living creatures, the world of objects, and nature in a communicational process that introduces them in the consumerist culture" ( $p$. 146).

\subsection{Political advertising and the rediscovery of intersubjectivity in the public space: secularization - catalyst of the sacred's energies}

In the democratic society, there is a distinction of electoral campaigns during which political advertising is permitted. During this time, it presents an important product on the advertising market. In this chapter, professor Frunza analyze the manner in which this market operates the perspective of political marketing.

A decisive aspect while distinguishing the products of business advertising and of political advertising may be based on the relationship between symbol, communication and memory. The product promoted by political advertising is charged not only with a typical symbolism, as it does not serve just as an exchange or communication means, but also with memory.

Professor Frunza evokes Lucian Sfenz's theory, relevant for political advertising discussion are "the bibles of the political". They are decisive in understanding political communication as "these theoretical memories have as much practical effectiveness as the colored flags that illustrate them, the seductive or repulsive images they give birth to, the communions they inspire. "We die and live to the same extent for them as for some abstract principles. One way or another, they represent two indissociable faces of the same mobilization phenomenon necessary to identification, that is, to identity" (Lucien Sfez, 2000, p. 149).

The importance of symbols, of ritualizing or of mythical figures is seen also in the new virtual world of the internet. The virtual world seems to tell an endless story: "Virtual worlds are rich with possibility for brand engagement, sales, market research, facility utilization, and entertaintment, but they are communities above all else. Participants interact with others using avatars as in-world representatives... Activities are seemingly endless' (Tracy L. Tuten, Advertising 2.0) nternet, the virtula world, is an inexhaustible source of contents and experience, and the central element which is enabled by the virtual world is the abundance, related to Information Age.

This context reveals a "special state of the relation between the media, religion and ideology, between ideological shaping and political action" (p. 169). Although at the same time with the development of media communication it becomes "quite visible that ideological differences between various groups participating in power or fighting for it are greatly diminished, the mass media is becoming a site favorable to ideological solidarity" (p. 169). It 
becomes a framework favorable to ideological creation in its position of space in which all instruments of persuation and manipulation are used.

\subsection{Final thoughts: the return of authenticity}

Advertising is an instrument of regaining authenticity. Storing an imaginary universe, which allows for the sacred to be manifest in the life of the postmodern man, "advertising supports the human being in its self quest through reaching harmony with the surrounding things" (p. 171), with other people and with the word. "Advertising is not a new form of religion, even though several of its aspects could be said to be displaying religious dimensions" (p. 171). Advertising offers an alternative view on the world, man and man's own choice to act coherently upon this view.

Everything that constitutes the postmodern human condition is engrained with communication. But we cannot generically affirm that communication constructs reality, although it serves as a foundation, as a network, as a superstructure of postmodern society. Such an affirmation about communication in the generic sense could set in motion a false belief in the existence of a communicational pantheism, capable of overlapping the objective reality and the created reality to the point in which they become one. In order to avoid totalitarian perspectives specific to both communication and knowledge, our perspective on this matter is that reality is constructed by advertising, and in this process, advertising is understood as a medium capable of storing the postmodern promises of sacredness. "Advertising is being produced and reproduced as a permanent refuzal of wholeness in favor of the fragmentary" (p. 172).

\section{CONCLUSIONS}

If we are not able to note that postmodern man becomes captive in communication media and pushes to a secondary plane the communication content, we would agree that the drama of the death of communication is in full process. At the same time, if we could note that due to the extraordinary development of communication media and their maximized function, postmodern man communicate excessively and cannot control message abundance, being no longer capable to receive and respond to the flow of communication requests, we might also say that he/she lives in full process anouncing the death of communication. Also, were we to note that postmodern man communicates only because he/she cannot help communicating, being addicted to communication, we might say that, for various reasons, he/she is part of communication reaching its end, and as a human being finds his/her own end in the captivity of communication. "We can say that adevertising, conclude professor Frunza, is art of saving appearences in the dynamics of buiding realities in the communication process" (p. 69). Zetetic core (research) is a theoretical ethics one and also applied ethics. This is a theoretical ethics in the public space of advertising. Overall, the book has cohesion and consistency. Therefore, it is a pleasant and instructive reading.

\section{References}

[1] Sandu Frunză (2014). Advertising Constructs Reality. Bucuresti: Tritonic.

[2] Sandu Frunza, Journal for the Study of Religions and Ideologies (29) (2011) 182-202. 
[3] Antonio Sandu, Postmodern Openings (3) (2014) 49-66.

[4] Andrzej Borowski, International Letters of Social and Humanistic Sciences 14 (2014) 3341.

[5] Ștefan Vlăduțescu, Xenia Negrea \& Dan Valeriu Voinea (2014). Interpersonal communicational manipulations. Postmodern Openings.

[6] Sebastian Kot, Beata Ślusarczyk (2014). IT Role in Supply Chain Collaboration. Current Communication Difficulties, 165.

[7] Mihai Coman (1999). Introducere în sistemul mass-media. Polirom

[8] Andrezj Borowski, International Letters of Social and Humanistic Sciences 6 (2013) 8690.

[9] Elena Unguru, Antonio Sandu (2014). A Socio-Legal Approach of Probation in Light of the New Penal Code. Restorative Justice Versus Retributive Justice. European.

[10] Sandu Frunza, Transylvanian Review 20(3) 140-152.

[11] Ștefan Vlăduțescu, Dan Valeriu Voinea \& Elena Rodica Opran (2014). Theory and practical of the paradoxist aesthetics. In Neutrosophy, Paradoxism and Communiction. Craiova: Sitech.

[12] Sandu Frunză, Revista de cercetare şi intervenţie socială (35) (2011) 180-193.

[13] Sandu Frunza, Journal for the Study of Religions and Ideologies 11(32) (2012) 3-17.

[14] M. Eliade (1992). Tratat de istorie a religiilor, cu o prefaţă de Georges Dumézil şi un cuvânt înainte al autorului, traducere de Mariana Noica.Bucureşti, Editura Humanitas.

[15] M. Eliade (1961). Images and symbols: Studies in religious symbolism. Princeton University Press.

[16] Florentin Smarandache, Stefan Vladutescu, Revista de Cercetare şi Intervenţie Socială, (46) (2014) 243-254.

[17] Ştefan Vlăduţescu, American International Journal of Contemporary Research 3(10) (2013).

[18] Ștefan Cojocaru (2005). Metode apreciative în asistența socială: ancheta, supervizarea, studiul de caz. Polirom.

[19] Antonio Sandu (2014). Elemente de sociologie. București: Editura Tritonic.

[20] Oprea-Valentin Buşu, Mirela Teodorescu, Daniela Gîfu, International Letters of Social and Humanistic Sciences 27 (2014) 82-93

[21] Răzvan Alexandru Călin (2014). Psychology of the Archetype Symbol in Orthodox Church Picture and Architecture. Neutrosophy, Paradoxism and Communication, 178.

[22] Charles Larson (2003). Persuasiunea. Receptare si responsabilitate. Polirom.

[23] Lucien Sfez (2000). Simbolistica politica. Iasi: Institutul European

[24] Tracy L. Tuten, Advertising 2.0: social media marketing in a web 2.0 world.

[25] Ștefan Vlăduțescu, International Letters of Social and Humanistic Sciences 15(2) (2014) 164-170. 
[26] Stefan Weber, 2002, "Medien konstruieren Wirklichkeit"? (Medienimpulse,Heft Nr. 40, Juni 2002)

[27] S. J. Schmidt (2000). Kalte Faszination: Medien, Kultur, Wissenschaft in der Mediengesellschaft. Velbrück Wissenschaft.

[28] M. Jeffries, M. (2010). The Art of Business Seduction: A 30-Day Plan to Get Noticed, Get Promoted and Get Ahead. John Wiley \& Sons.

[29] Ștefan Vlăduțescu \& Florentin Smarandache (2014). Five Computational Actions in Information Processing. Social Sciences and Education Research Review, 2.

[30] Janusz Grabara, Michal Kolcun, Sebastian Kot, International Journal of Education and Research 2(2) (2014).

[31] A. Sandu (2009). Tehnici afirmativ-apreciative. O sociopedagogie a succesului. Lumen.

[32] A. Caras, A. Sandu, Procedia-Social and Behavioral Sciences 149 (2014) 142-151.

[33] A. Sandu, Postmodern Openings (3) (2014) 49-66.

[34] B. Ślusarczyk, R. Golnik, R. The recruitment process in transnational corporations. Journal.

[35] Florentin Smarandache \& Ștefan Vlăduțescu (2014). Communicative Universal Convertibility Matter-Energy-Information. Social Sciences and Education Research Review, 1.

[36] C. M. Bunăiașu, Ș. Vlăduțescu, A. C. Strungă Revista Romaneasca pentru Educatie Multidimensionala 6(2) (2014) 17-27.

[37] M. G. Mangra, E. A. Cotoc, A. Traistaru, Journal of Studies in Social Sciences 6(1) (2013).

[38] J. H. Gasderell, International Letters of Social and Humanistic Science 22 (2014) 85-91.

[39] Ștefan Cojocaru (2005). Metode apreciative în asistența socială: ancheta, supervizarea, studiul de caz. Polirom.

[40] J. Habermas (1987). Theory of Communicative Action. Volume 2, Boston: Beacon Press.

[41] Andrzej Borowski, International Letters of Social and Humanistic Sciences 14 (2014) 717.

[42] D. Cojocaru, A. Sandu, S. Cojocaru, Journal for the Study of Religions and Ideologies (28) (2011) 65-83.

[43] Maria Nowicka-Skowron, Sorin Mihai Radu (2014). Innovation process modelling. Current Communication Difficulties, 104.

[44] Max G. Craig, Journal of Studies in Social Sciences 8(1) (2014).

[45] Ștefan Vlăduţescu (2014). Actants of manipulative communication. International.

[46] S. Cojocaru, A. Sandu, S. Ponea, Social Research Reports 8 (2010).

[47] A. Borowski, International Letters of Social and Humanistic Sciences (27) (2014) 100110.

[48] A. Sandu, E. Unguru, Procedia-Social and Behavioral Sciences 82 (2013) 386-391. 
[49] A. Borowski, International Letters of Social and Humanistic Sciences (04) (2013) 70-74.

[50] J. Habermas (2000). Conştiinţă morală şi acţiune comunicativă. Bucureşti: Editura All Educaţional.

[51] Jason L. Powell, International Letters of Social and Humanistic Sciences 17(1) (2014) 160. 